Politics of safety

\section{Influence of free trade on the politics of safety}

\section{E McLoughlin, A Fairweather}

Why injury prevention is essentially political

W hen advocating for prevention strategies, public health professionals need to recognize who the stakeholders are and the conflicting values they bring to negotiations. In politics, deals are struck and decisions are made, dependent upon the relative power and valued "goods" held by divergent interested parties. In the politics of safety, it is the responsibility of injury prevention advocates to further the interests of public health and safety as powerfully as possible.

This has never been an easy task and new, widely unrecognized challenges may now make it even harder. The movement towards globalization and unfettered free trade has extreme relevance to the international politics of safety, and for national, regional, and local jurisdictions as well.

Globalization and trade issues may seem far afield from the day to day concerns of the injury prevention community. But colleagues in other fields, like environmental protection, have been active in trying to influence decision making. Injury prevention cannot remain uninvolved.

\section{WHY INJURY PREVENTION IS ESSENTIALLY POLITICAL}

In the 1970s, Dr William Haddon proposed that we apply fundamental principles of disease prevention to injury control-host, agent, and environment, as factors amenable to modification, and thus prevention. Efforts to modify host factors through behavior modification are usually politically safe because they place responsibility on the individual to change, not on the corporations that manufacture these products.

Efforts to change agents or vectors, most often consumer products, however involve decisions about design, manufacture, and sale. These are based on a variety of concerns that sometimes include safety. Debates about how to balance these factors are often contentious, pitting consumer advocates against antiregulatory and proindustry forces. These debates are usually associated with the regulatory and/or legislative process.

\section{HOW TRADE CONSIDERATIONS THREATEN INJURY PREVENTION}

Traditionally, establishing health and safety regulations has been the prerogative of national and sometimes regional governments acting on behalf of their own citizens and residents. Now, this power is shifting to multinational trade organizations, primarily the World Trade Organization (WTO).

The WTO was established in 1994 to administer the Global Agreement on Tariffs and Trade (GATT), and is charged with eliminating trade obstacles and resolving international trade disputes. Trading partners can challenge the regulatory policies of sovereign nations as being "technical barriers to trade".

These regulations go to the core of injury prevention and include, for example, manufacturing standards, worker safety protocols, auto and aviation safety, labeling requirements, chemical manufacture and flammability controls, and any other safety standards related to goods.

When one country formally challenges the policies of another, including those related to safety regulations, a panel of WTO arbitrators is called on. There is no public access to the dispute procedure, no intervention by nongovernmental organizations, and no opportunity for independent appellate review.

Many environmental, public health, and safety standards have not survived trade challenges. WTO officials are quick to point out that "losing" countries are not forced to abandon domestic policies. But if they choose to retain their own standards, they are required to pay "winning" disputant countries permanent fines and/or increased tariffs on other, unrelated, exports. In fact, authorities have lowered their protective standards as a result of or in anticipation of trade challenges.

\section{HOW TRADE THREATENS THE DEMOCRATIC PROCESS OF SAFETY REGULATION}

In the global trade world, the term "injury" refers not to broken bones, bullet wounds, and burns, but to economic harm. There is a fundamental conflict between injury to private enterprise and fatal or disabling injury to people, played out between the systems designed to avoid each type of injury. When economic systems overpower all others, health and safety suffer. The purpose and mission of the WTO and North American Free Trade Agreement (NAFTA) is to liberalize trade. They must deal with other considerations because they can not completely separate themselves from society. But language discussing the importance of health and safety is only preamble, and has no legal significance. Clearly, there are competing interests and these present challenges to public health.

The WTO presents several additional obstacles to those already battle scarred by advocacy for national safety regulations.

\section{Necessity test}

Regulations must pass a rigorous "necessity test", wherein regulators must show that there is no less restrictive way to achieve their public safety goal. But we rarely know the entire spectrum of possible interventions to address a particular problem. What may be less restrictive in one country may be judged more restrictive in another and thus unacceptable to the WTO. "Necessity" comes from negotiation of the trade agreement and panelists use "jurisprudence" from other trade disputes in their interpretation of this law.

\section{Risk assessment}

Health and safety is not an exact science. We strive to prevent as much injury as possible, which involves prioritizing values. In the areas of food safety and chemical hazards, the potential for serious injury or unknown outcomes may call for a "zero tolerance" approach or the application of the "precautionary principle", which requires industry to prove the long term safety of their product. The issue here boils down to priorities: Do we err on the side of caution or do we promote trade above all else?

Under WTO "risk assessment" standards for harmonized regulation, the burden is switched. Governments and public health policy makers must prove that industry action will result in long term harm in order to justify regulatory restrictions. This creates a nearly impossible task for public health professionals.

Standardization or "harmonization" To streamline trade and prevent future disputes, WTO works with member countries to harmonize regulatory rules and protocols for assessing public safety. There is no inherent reason that regulatory cooperation is contrary to public health and safety. The question remains, 
however, whether international standards will reflect the higher safety levels or the lowest common denominator. The problem to date is that WTO standards and provisions provide a ceiling, not a floor, for safety regulation. As such, any domestic flammability, transport, or worker safety protocols that go beyond the international standards would be vulnerable to trade barrier challenge.

\section{Acceptable data}

Harmonization can also have a direct impact on public health data collection practices. For example, proposals for harmonized medical safety device reporting requirements preclude reports of risk. Current standards include reporting events that cause or contribute to injury and death and events that if repeated could cause or contribute to injury and death. The proposed harmonization reporting standard includes only those cases in which injury occurs, not where repeated episodes would present risk. The whole point of harmonization is that each country cannot adopt its own standards-they must agree to abide by the harmonized rules. If they were to adopt higher standards, these could be challenged as being a technical barrier to trade- that is, a basis for preference.

\section{Equivalence determinations}

Another threat to domestic public health safeguards is through "equivalence determinations". Is one nation's safety regulation considered "sufficiently comparable" to another nation's regulation, so that regulated products are equivalently protected in both nations? When significant methodologic differences are overlooked in these assessments, safeguards can be weakened.

\section{Ability to sue}

WTO rules allow only member governments to file disputes against one another. However, the NAFTA allows investors (corporations) to challenge national and local government regulation which they allege would damage future profit making. The only public access to these challenges are the initial complaints and final awards.

Governments have competing interests including public safety, international relations, and economic factors, when deciding whether or not to challenge another nation's laws in a trade forum. Corporate officials, however, have one over-riding consideration-to increase profits for their shareholders. This specter of multimillion dollar claims by domestic and foreign corporations creates tremendous obstacles for regulation.

\section{A CASE IN POINT: ALCOHOL POLICY AND WORLD TRADE}

Alcohol consumption has immense public health costs associated with injury. To reduce alcohol related problems, advocates have built the case for regulations regarding price (primarily in the form of alcohol taxes), marketing (often regarding advertizing), and distribution (often through state monopolies and control over licensing for liquor outlets).

\section{Alcohol policy and GATT}

The prime objective of free trade is to increase trade and consumption, including that of alcohol. Several national alcohol policy measures have been challenged in trade disputes. For example, the EU challenged Chile's progressive alcohol taxation system as a trade violation. Chile taxed its local beverages with lower alcohol content at a rate lower than higher alcohol content imports. The EU argued that all alcoholic beverages were "like products". Chile countered that alcohol content was a neutral category, and that the alcohol content created different "products". Thus, any effect on foreign imports was an unintended consequence of their legitimate tax system. WTO found in favor of the EU.

In another case, the European Court of Justice found that Swedish alcohol advertising restrictions were an obstacle to trade within the European Union. The law, which had been passed for the express purpose of reducing alcohol related harm, disallows ads that encourage alcohol consumption. To preserve these restrictions, Swedish authorities are now obliged to prove to trade officials that the measure is proportionate to its goal, that there are no alternative approaches that would be less restrictive, and that the regulation is not arbitrary, discriminatory, or a protectionist measure in disguise.

\section{ANOTHER CASE IN POINT: TRUCK SAFETY AND THE NAFTA}

NAFTA was established in 1994 to liberalize trade between Canada, the United States, and Mexico. A contentious issue has been the safety standards of large commercial trucks. Canada and the US had much tougher truck safety standards than did Mexico. As negotiated, NAFTA scheduled unrestricted cross border trucking to begin in 2000, when standards were expected to be unified at US or Canadian levels. Until then, Mexican trucks were required to meet US standards while traveling within a restricted 20 mile US trade zone. In January 2000, the Mexican standards had not been improved so the US refused to expand the trucking zone. Mexico filed a dispute and the NAFTA panel ruled in its favor. To assure compliance with US standards, the US must inspect each truck at the border crossing. Border crossings, however, lack the capacity to handle comprehensive inspections of every commercial truck. In December 2001, the US Congress passed legislation to expand access to Mexican trucks beyond the existing 20 mile wide border zone, and to provide additional funding for increased border inspections. Even so, it is unlikely that border officials can inspect every single truck.

\section{WHAT WE NEED TO DO NOW}

We must quickly join with organizations already immersed in these issues. Two good places to start are the web sites of the Council of Canadians (http:// www.canadians.org/) and Public Citizen's Global Trade Watch (http:// www.publiccitizen.org/trade/index.cfm). The Council of Canadians, established in 1985, is the pre-eminent citizen's corporate and government watchdog group dedicated to preserving Canada's social services, environmental safeguards, and national sovereignty. Public Citizen, founded in 1971 by Ralph Nader, is a national (US) non-profit public interest organization which aims to protect health, safety, and democracy. Both sites can be considered a gateway into these issues for the injury field and provide up to the minute information of developments, identify issues that must be challenged, and provide tools that advocates can use to make their voices and concerns heard.

A valuable document: The Arms Trade Revealed: A Guide for Investigators and Activists was published in 1998 by the Federation of American Scientists Fund. While it addresses advocacy efforts around the control of small arms trafficking, it can also be useful for injury prevention advocates beginning to tackle the enormous challenges to health and safety posed by global trade. It identifies seven essential elements in the work:

\section{(1) Leadership}

The work requires "savvy, determined, and communicative" leadership that will "identify a clear objective, develop a workable plan of action for achieving that objective, and communicate that plan to allies and partners in a timely manner" and then report back on developments and next steps.

\section{(2) Coalition building}

Building a critical mass is vital, and that requires reaching out to particularly influential or unusual allies. By joining existing coalitions, injury prevention advocates can swell existing numbers and sharpen a focus on injury that has not been very apparent to date.

\section{(3) Sharp focus}

Big, diffuse issues can seem overwhelming and paralyzing. Successful campaigns have a narrower and more discrete focus. The injury field may want to identify certain issues around which it will organize. 


\section{(4) Consistent message}

Establish a message and keep to it, and "do not shy away from moral and humanitarian arguments". Also, "bring the voices of victims to the public, press, and policy makers. Personal testimony is very powerful".

\section{(5) Solid analysis}

"Solid analysis is necessary to make and back up your case. Link a carefully developed research agenda closely to policy, press, and grassroots strategies".

\section{(6) Political allies}

Find and groom political leaders and their staffs who can be influential in furthering our goals.

\section{(7) International efforts}

This will take advantage of the expertise and differing perspectives represented within the international injury prevention community. Since global trade disputes may pit our nations against each other, it will be important to conduct candid analysis of the issues in the light of injury control principles in addition to those of economic national interests.

The Sixth World Conference on Injury Prevention and Control will be held in Montreal, Canada from 12-15 May 2002. The international injury prevention field may want to adopt the elements set forth in the activists' guide to become participants in the movement to influence global trade debates for the protection of the health and safety of all peoples.

This paper is a revised version of a presentation entitled The Politics of Safety-from Local to Global, given at the Injury Prevention Network of Aotearoa New Zealand 2001 Conference, held in Wellington, NZ in November, 2001.

Injury Prevention 2002;8:3-5

Authors' affiliations

E McLoughlin, A Fairweather, Trauma Foundation, San Francisco General Hospital, San Francisco, California, USA

Correspondence to: Dr E McLoughlin, San Francisco Injury Center, San Francisco General Hospital, Building 1, Room 400, 1001 Potrero Ave, San Francisco, CA 94110, USA

\section{REFERENCES}

\section{RE: WORLD TRADE}

A Citizen's Guide to the World Trade Organization, published by the working group on the WTO/MAl, July 1999, ISBN 1-58231-000-9

(http://www. publiccitizen.org)

Dispute Settlement Body Minutes of Meeting World Trade Organization. WT/DSB/M/73 (00-0430), 4 February 2000 (available from http://docsonline.wto.org).

Harmonization Handbook, Accountable Governance in the Era of Globalization: the WTO, NAFTA, Public Citizen Global Trade Watch (http://www. publiccitizen.org/ publications).

Principles of Harmonization, TransAtlantic Consumer Dialogue, Doc No Trade 08-00 February 2000 (http://www.tacd.org/)

Pollock AM, Price D. Rewriting the regulations: how the World Trade Organization could accelerate privatization in health-care systems. Lancet 2000;356:1097

(http://www.thelancet.com/).

\section{RE: ALCOHOL}

Grieshaber-Otto J, Schacter N. The GATS: Impacts of the international "services" treaty on health-based alcohol regulation. National Research and Development Centre for Welfare and Health (Stakes), July 2001 (http://www.stakes.fi/english/).
Grieshaber-Otto J, Jernigan D. Trade, treaties, alcohol and public health. Globe Magazine New Series No 2, 2001

Trachtman JP. Chile-taxes on alcoholic beverages. Current developments decisions of the appellate body of the World Trade Organization Survey. European Journal of International Law 12 January 2000 (http://www.ejil.org/journal/).

\section{RE: NAFTA}

The Coming NAFTA crash: the deadly impact of a secret NAFTA tribunal's decision to open US highways to unsafe Mexican trucks new evidence suggests that a NAFTA ruling allowing Mexican trucks access to US will expose the public to significant threats. Public Citizen Global Trade Watch, February 200 (http://www. publiccitizen.org)

Free Trade Area of the Americas Draft Agreement. Derestricted FTAA TN C/w/133/Rev 1, July 3 , 2001 (http://www.ftaa-alca.org/).

NAFTA Chapter 11. Investor-to-state cases: bankrupting democracy lessons for fast track and the free trade area of the Americas. Public Citizen and Friends of the Earth, September 2001 (www.publiccitizen.org).

\section{RE: ADVOCACY}

Lumpe L, Dunarski J. The arms trade revealed: a guide for investigators and activists.

Washington, DC: Federation of American

Scientists Fund, August 1998

(http://www.fas.org/asmp).

\section{WEB SITES OF INTEREST}

\section{PRIMARY}

- Council of Canadians: http://www.canadians.org/ (click on Campaigns, then on Trade $\&$ Investment Issues)

- Public Citizen Global Trade Watch: http:// www.publiccitizen.org/trade/

\section{OTHERS}

- Free Trade Area of the Americas (FTAA) Official web site: http://www.ftaa-alca.org/

- International Forum on Globalization: http:// www.ifg.org/index.html

- NAFTA Secretariat: http://www.nafta-secalena.org/

- Trans-Atlantic Business Dialogue: www.tabd.org/

- Trans-Atlantic Consumer Dialogue: Www.tacd.org/

- World Trade Organization: http://www.wto.org/ 